Шуйський I. В.

науковий редактор сектору редакиії книги «Реабілітовані історією» КП «Регіональний інформаційний ичентр» Харківської обласної ради

\title{
ТОРГСИН ЯК ОДИН ІЗ СИМВОЛІВ ГОЛОДОМОРУ У ТВОРАХ УКРАЇНСЬКИХ ПИСЫМЕННИКІВ
}

У статті вперие досліджені літературні джерела художніх творів українських письменників, у яких висвітлюється торгівельна мережа «Торгсин». Ї̈ діяльність напряму пов'язана з итучно створеним у 1932-1933 роках Голодомором.Крамниці торгсинів функціонували по всій території України. Створені з метою задоволення потреб чужоземиів, вони в умовах Голодомору були зорієнтовані на обмін изіностей населення Украӥни - золота, срібла, діамантів. Використовуючи зубожілий стан населення і дефіцит, радянська влада встановила несправедливий курс обміну. Більшість потенційних покупців, переважно селян, були не в змозі обміняти продукти і помирали під дверима торгсинів. У свідомості багатьох украӥнців торгівельні точки з написом «Торгсин» закарбувалися як символ «великого голоду».

Діяльність торгсинів була засекречена і не висвітлювалась на сторінках газет, публічно не обговорювалась. Радянські письменники під загрозою репресій уникали згадок про торгсини, бо добре розуміли причини появи голодних селян на вуличях міст, виникнення нескінчених черг біля крамниць. Це підтверджують художні твори, опубліковані за кордоном. Враження $і$ документальні події у столииі радянської Украйни висвітлили Олесь Гай-Головко, Олена Звичайна та Михайло Млаковий. Емоційно насичені твори Зосима Дончука оповідають про перебіг торгівлі на периферії. Письменниия Ольга Мак спробувала знайти відповідь на питання, яку роль відводила торгсинам радянська влада.

Вперше автор статті проаналізував варіанти вживання у літературних творах назви торгівельної мережі, які мали суттєву відмінність. Автор довів, єдиним вірним варіантом є «Торгсин», який використовують у роботах сучасні украӥнські історики.

Ключові слова: крамниця, «Торгсин», письменник, роман, голод.

In this article, the literary sources of artistic works by Ukrainian writers, which highlight the network of "Torgsin" stores, are first explored. Activities of and around Torgsin stores are directly related to the Holodomor, the artificially created famine in 1932-1933.

Torgsin stores operated throughout the territory of Ukraine. Created to meet the needs of foreigners, they were focused on the exchange of valuables owned by members of the Ukrainian population during the Holodomor-gold, silver, and diamonds. Torgsin stores were located in the central places and attracted the attention of customers with shining shop windows and the presence of bread, flour, groats. The Soviet government used the deficit and established an unfair exchange rate. Most potential buyers, mainly peasants, were not able to exchange products and were dying under in the stores' doorways. In the minds of many Ukrainians, the trade outlets bearing the inscription "Torgsin" became synonymous with the symbol of "great hunger". 
Torgsin's activities were classified and not covered on the pages of newspapers, and were not publicly discussed. There was talk around them, there were gossip.

Soviet writers avoided mentioning these stores. Writers well understood the causes of the appearance of hungry peasants on the streets of cities and the emergence of infinite queues at Torgsin. This is confirmed by artistic works published abroad. Impressions and documentary events in the capital of Soviet Ukraine were highlighted by Oles Gai-Golovko, Olena Zvichayna and Mykhailo Mlakoviy. The emotionally rich works of Zosim Donchuk tell about the course of trade on the province. The writer Olga Mack tried to find an answer to the question of what role the Torgsin stores were given by the Soviet authorities.

The author of the article first analyzed various excellent ways of using the name of the trade network in the literary works. The author proved that the only correct option is "Torgsin", which is used by modern Ukrainian historians in works.

Keywords: stores, «Torgsin», writer, novel, famine.

Діяльність торгівельної мережі крамниць «Торгсин», покликаної в 1931-1933 роках «мобілізувати» валюту та цінності голодного населення, напряму пов'язана 3 Голодомором. У свідомості багатьох українців торгівельні точки 3 написом «Торгсин», кількість яких зі скасуванням карткової системи поступово зменшувалася до повного зникнення, закарбувалися як символ «великого голоду». Утім ця тема майже не обговорювалась на сторінках радянської преси, не включалася до сюжетів літературних творів, творчих дискусій.

До здобуття Україною незалежності тема Голодомору 1932-1933 років залишалася забороненою. Публікації робіт репресованих авторів показали, що нерозглянутими залишаються окремі аспекти, серед яких діяльність Всесоюзної контори «Торгсин». До нечисленних художніх джерел належать твори письменників української діаспори, які нині зостаються маловідомими дослідникам, читацькому загалу в Україні. Метою статті $€$ вперше провести аналіз присвячених темі літературних творів, уточнити біографічні дані їх авторів, переважно представників української діаспори.

Радянські письменники належали до найбільш поінформованої частини суспільства. Однак їх сміливі оцінки механізму штучно створеного голоду, кількості померлих не мали виходу на публічне обговорення. Стиснуті лещатами цензури і небезпідставними погрозами наглядачів ДПУ, автори були вимушені дедалі більше звужувати коло можливих тем і сюжетів.

За рознарядками керівництва, письменників спрямовували в села у якості покликачів, що виправдовували і адаптували політику на селі. Надаючи приклад «активної громадянської позиції», «Літературна газета» сповіщала про Григорія Епіка, Володимира Сосюру, Миколу Шеремета, Сергія Пилипенка, які на початку 1933 року «добровільно мобілізувалися для участі в хлібозаготівельній кампанії у відсталих районах Одеської, Харківської та Дніпропетровської областей» [15].

Враження від людиноненависницької практики хлібозаготівель не легко уживалися в свідомості митців і спричинили психічний розлад у Володимира Сосюри. «Великий організований голод і терор 19321933 років, самогубство Хвильового i Скрипника, постійне чекання арешту й розстрілу довели були Сосюру до повного нервового розладнання», вважав Юрій Лавріненко, додавши, «можливо, цим він урятувався від фізичного знищення» [16, с. 175]. Версію особистої трагедії поета виклав у третій частині опублікованого в Канаді роману-трилогії «Золотий дощ» [14] письменник і громадсько-політичний діяч Павло Маляр.

Героїня роману, студентка харківського медичного інституту Уляна, зустрілася 3 Володимиром Сосюрою під час практики в клініці при психіатричній лікарні на $\mathrm{Ca}-$ буровій дачі, яка, вочевидь, відносилась до Українського інституту клінічної психіатрії і соціальної психогігієни. Вигляд Сосюра мав кепський. Проте його це бентежило не стільки, як звинувачення у відсутності нових оптимістичних віршів. Радянська система і за стінами лікарні не залишала хворих у спокої, залучаючи до ідеологічних заходів. На питання працівника обкому партії, чому той оплесками не підтримав тезу доповіді про прийдешнє покращення життя, поет відповів, «що він не божевільний, а покараний божевіллям» [14, с. 69]. 
Лікування психічної хвороби було чи не найменшим лихом у письменницькому середовищі тієї доби. Не вдаючись ухилитись від примусової мобілізації, дехто намагався накласти на себе руки. Суїцид офіційно трактувався як акт політичний i дорівнювався «дезертирству». Не довіряючи одностайній позиції, висловленій редакцією «Харківського пролетарія» у некролозі Миколи Хвильового («ми не можемо не ставитися 3 осудом до безглуздого кроку», «М. Хвильовому забракло революційного гарту») [18], ДПУ негласно збирало думки [17, с. 187-191] і не цуралося напряму цікавитися про ставлення до події.

Зрештою, героїня роману на собі відчула негативні симптоми паралельного існування протилежних систем цінностей у радянському суспільстві. Символічно, що за сюжетом твору, порятунком Улянки від праці «на благо світлого майбутнього» було звільнення через зарахування лікарні до закладів «закритого типу», у яких тримали «політичних злочинців» і осіб, ізольованих за людоїдство під час голоду. Виведена автором ситуація слугувала метафорою, яка пояснювала причини від'їзду за кордон творчих особистостей.

Українська діаспора прийняла письменників і створила умови для підготовки публікацій, у яких висвітлено літературнохудожнє явище цілої історичної епохи. Митці успішно довели, що за драматичністю актуальна тема торгсинів мала бути однією із центральних у 1932-1933 роках. Подумки повертаючись до трагічних подій в Україні, вони підсилювали оповідь соціальним контрастом, яскравими описами достатку вітрин і полиць, виводили у центр сюжетів ситуації навколо торгсинівських приймальних пунктів.

Поет і письменник, літературознавець, член Всеукраїнської спілки пролетарських письменників Олесь Гай-Головко (Олекса Нестерович Гай-Головко) працював редактором Харківського радіокомітету, виконував обов'язки відповідального секретаря популярного часопису «Червоний шлях». Залишивши наприкінці Другої світової війни батьківщину, він підготував автобіографічний твір «Поєдинок 3 дияволом: фільми наших днів», у якому описав побачене в го- лодному Харкові після повернення 3 досить благополучного Ленінграду. Торгсин сприймався автором як виняткова крамниця, наповнена вишуканою їжею, під вітринами якої вмирали голодні українці [1, с. 37].

В іншому автобіографічному творі Гай-Головка наведена маловідома, пов'язана 3 торгсином історія. Випадок нібито стався при відвідуванні СРСР відомим французьким політиком Едуардом Ерpio. У серпні 1933 року на шляху з Одеси до Москви йому готували містифікації, знайомлячи 3 «щасливими працівниками радгоспів», колгоспниками і містянами із переодягнених акторів. У Харкові до ознайомчого маршруту включили центральну торгсинівську крамницю. Заздалегідь підготувавшись, працівники ДПУ і комунальники прибрали 3 вулиць все, що натякало на кризу, аби «приховати апокаліптичну дійсність в Україні від Ерріового ока» [2, с. 259]. Замінили вивіску новою назвою «Торгскол», яку розшифрували гостеві як «торгівля 3 колгоспниками». Вражений суцільним достатком, Ерріо придбав кілька пачок найдорожчих цигарок і бляшанок чорного та червоного кав'яру $[2$, с. 260]. Фокус із вивіскою «Торгсину» вдався. Центральні радянські газети, які висвітлювали кожний крок Ерріо по українській землі, навіть не повідомили про відвідування крамниці.

Мер міста Ліон, колишній прем'єрміністр Франції обрав зручну і вигідну позицію політичної короткозорості. «Відносно України, яку я об’іхав, казали, що вона спустошена голодом і в той самий час пропонували колонізувати іiі. Так от я можу вам сказати, що я бачив нарід, який докладає величезні зусилля, країну, що індустріалізується, опановує знання, запровадивши закон про обов'язкове навчання» [9]. Eppio намагався вирішувати задачі великої політики, що почасти пояснювало таку гнучку поведінку. «Сьогодні я перед французьким народом і я кажу йому: "Хiба ви не щасливі, що заради миру й спокою ваших родин i ваших дітей ми намагаємося скористатися всіма можливостями, намагаємося договоритися з великим народом?"» [9].

Спроби домовитися 3 можновладцями, нехтуючи стражданням народу, викликали розпач і ненависть у мешканців голо- 
дного Харкова, які сподівалися на допомогу Заходу. «...він не помітив у час відвідин ніяких ознак голоду в Україні - голоду там не було й немає... Так? - убити б гада! казали. Лука убив би!»- стверджував герой Павла Маляра [14, с. 55-56].

Теми харківського «Торгсину» торкнулися Олена Звичайна та Михайло Млаковий (за справжнім прізвищем подружжя Джулів) у документальній двотомній повісті «Ворог народу», яка здобула першу нагороду конкурсу Українського літературного фонду ім. Івана Франка в Чикаго 1967 року [11]. Співавтори прагнули розкрити об'єктивні причини трагічних подій $\mathrm{XX}$ століття на теренах радянської Україні. Використаний основний мистецький засіб - не лише детальний опис обставин, це їх яскрава демонстрація у серії картин. «Автори не оповідають і не характеризують героїв чи персонажів від себе. Вони їх показують, немов на фільмовому екрані, де картини змінюються за поворотами фільмового апарату. Групи картин творять далі природні етапи життєвого, характерологічного та ідейного буття наших героїв», - визначив у передмові професор Володимир Шаян [19, с. 12].

Розповідь про голод супроводжував опис крамниці «Торгсин», що містилася на столичному майдані. Саме туди тягнулися сім'ями і поодинці голодні, які завмирали, оглядаючи вітрини, заставлені найрізноманітнішими стравами. «А в самому центрі цього харчового багатства, як справжній господар становища, як пан над панами, ясніло білесеньке борошенце з червоною етикеткою "000"» [11, с. 282]. Ковтаючи «замість шинки слинку», зубожілі селяни доходили під білими мурами будинку ВУЦВК, навпроти редакції газети «Комуніст», зі шпальт якої щоденно лунали заклики «ліквідувати куркуля як клас». Звідти ледь живих бідолах разом із підібраними тілами померлих вивозили за місто вантажівками i скидали в яри та канави. Ціна мільйонів людських життів українців дорівнювала вартості збіжжя, проданого за кордон за демпінговими цінами. Автори нагадали про заборону, коли необережне вживання слова «голод» коштувало волі й життя.

Ситуацію, коли в умовах харчового дефіциту торгсинівська «валюта» ставала предметом спекуляції, О. Звичайна показала на прикладі однієї із героїнь повісті «Селянська санаторія». Незважаючи на брак грошей, заповзятлива мати намагається придбати хворій дочці курортну путівку. Їй це вдається, продавши отриману в обмін на золоті обручки грошову книжку «Торгсину» $[10$, с. 15$]$.

Письменниця Ольга Мак (Ольга Нилівна Петрова, удова репресованого вченого мовознавця В. О. Дорошенка), відверто згадувала Харків 1933 року «як щось таке подібне до величезної могили, де половина людей ще живе, а половина людей вже мертва» $[13$, с. 103]. Сюжет повісті «Каміння під косою» побудований навколо цінностей, які в умовах штучно створеного голоду $\epsilon$ чи не єдиним засобом врятувати життя. У діалозі шляхетної українки Лідії Сергіївни Чернявської з порятованим сільським підлітком Андрієм письменниця розмірковує про роль, відведену торгсинам радянською владою. «Щоб дітей підгодувати, не одна мати в "Торгсін" шлюбні обручки віддає i не задумується над тим, що ті обручки влада в кайдани на руки ії дітям переробить; що золотий хрестик, зданий в "Торгсін", виросте в Голгофський хрест для іiі сина; що дорогоцінний камінець обернеться в цілу купу сирого каміння, призначеного на будову нової тюрми; що за брошку зроблять знаряддя для тортур; що за золоті монети годуватимуться сексоти та гепеушники, які триматимуть на ланцюгах врятованих від голоду дітей» $[12$, с. 146]. На іiі думку, обмінні пункти торгсинівських крамниць слугували зміцненню тоталітаризму. Змушені виживати, українці не замислюючись робили внесок у становлення режиму, забувши про національну гідність і державну незалежність.

Закликаючи до торгсинів нових потенційних клієнтів, влада водночас презирливо ставилася до виснажених людей, особливо тих, хто вже не мав запропонувати нічого цінного. Автор виданої Спілкою української молоді Америки новели «Голод», який скрив повне справжне ім'я за ініціалами «РМ», навів частину діалогу партійних функціонерів. В очікуванні секретаря ЦК КП(б)У Станіслава Косіора, секретар Київського обкому КП(б)У Ільїн дав члену об- 
кому Чернишу вказівку: «зайди в Торгсін і скажи, щоб закрили вітрину!.. а то завжди там, наче обласний з'їзд бродяг!» [8, с. 7].

Член українського письменницького об'єднання в еміграції «Слово» Зосим Іванович Дончук чимало творчості присвятив темі голоду. За його визнанням, часто доводилося чути закиди «що я, переживши чорну дійсність, не здатний, мабуть, бачити світу у світлих тонах» $[7$, с. 5]. Потрібно зауважити, Дончук встиг зіткнутися з голодом і на волі, і у в'язниці ДПУ. Розповіді письменника не обходилися без згадки про Торгсин. У романі «І бачив я...» Дончук надав опис міської крамниці [4, с. 180], у новелі «Останній Великдень на Полтавщині» відтворив сільський «обмінник», у якому селяни вимінювали декілька фунтів борошна на золоті натільні хрестики [5, с. 41].

Емоційно забарвлений епізод навів автор у романі «Прірва», коли вінничанка Оксана вирішує пожертвувати золотими коронками, щоб прогодувати трьох маленьких дітей. Величезним приниженням і зневірою скінчився іiі візит до крамниці. Оксана дізналася, що тї 3,5 грами золота дорівнювали торгсинівським 2 карбованцям 17 копійкам, на які можна було купити тільки вісім кілограмів манної крупи або 10 кілограмів пшона [6, с. 305-307]. У передмові збірника, присвяченого ювілею Дончука, письменник Анатоль Галан (Анатолій Васильович Калиновський) підкреслив типовість ситуації. «Під тиском голоду, ця дружина йде до дантиста й просить зняти в неї золоті коронки з зубів, аби за них щось купити в «Торгсіні». Перебільшення? Згущення фарб? Аніскільки!» [3, с. IX].

Вживання у літературних творах назви торгівельної мережі мало суттєву відмінність. Назва Всесоюзного об'єднання поступово стала відомою через поширення торгівельної марки «Торгсин», що включало стиснення російською «Торговля с иностранцами». Разом із привнесеною Москвою назвою, письменники подекуди використо- вували україномовні варіанти «Торгсін», «Торгзін» із відповідним розшифруванням. Ця звичка деякою мірою залишилась і нині, що не відповідає лінгвістичній та історичній традиціям. У 1920-1930-ті роки літератори, журналісти, службовці користувались академічним російсько-українським словником за редакцією А. Кримського, С. Сфремова (1924-1933), термінологічним словником ділової мови (1930), у яких відповідником слову «чужоземець» пропонувалось російське «иноземец». На цій темі зупинився відомий мовознавець, професор Юрій Шевельов (Шерех). В українській мові, коли йдеться про походження 3 інших країн, частіше вживається слово «чужий». Тоді як українське слово «іноземний» $є$ рідковживаним і належить до характеристик продуктів землі, вважав він. У російській мові, навпаки, слово «"чужой" вживається в значенні "не наш", але той, що походить 3-за кордону, - "иностранный"» [20]. У роботі про намагання в політичній літературі радянської України «точно відтворювати букву російського тексту», Шевельов дійшов висновку, що «за зразком російської мови значення слова "чужий" звужується, а значення слова "іноземний" поширюється» [20].

Згубні процеси, що розгорнулися в українській літературі на початку 1930-х років, завадили письменникам до осмислення руйнації, яка відбувалася в радянській Україні. Заповнити виниклі лакуни художньо-документальними творами про Голодомор і його наслідки спроміглися письменники української діаспори - свідки, яким пощастило покинути «країну рад», виїхавши за кордон. Образ «Торгсину» став тим засобом, який органічно вклався в загальну архітектоніку творів. Висвітлені особливості функціонування торгсинівських крамниць надають роботам художнього реалізму, послуговують безцінним історичним джерелом досліджень Голодомору.

\section{ЛІТЕРАТУРА}

1. Гай-Головко О. Поєдинок з дияволом: фільми наших днів / О. Гай-Головко. Вінніпег, 1950. 143 c.

2. Гай-Головко О. Смертельною дорогою: Події нашого часу / О. Гай-Головко. Вінніпег, 1983. 283 c.

3. Галан Анатоль. Передмова // Праияя $і$ нагорода Зосима Дончука / Упоряд. Л. Дончук. Філадельфія: Власна хата, 1973. C. V-XIII.

4. Дончук 3. І бачив я... : Роман. Філадельфія, 1967. $324 \mathrm{c}$. 
5. Дончук 3. Останній Великдень на Полтавщині // Чорні дні. Буенос-Айрес, Філадельфія, 1952. C. 39-43.

6. Дончук 3. Прірва. Чикаго, 1959. 560 c.

7. Дончук 3. Через річку. Буенос-Айрес: Перемога, 1953. $140 \mathrm{c}$.

8. Ерем. Голод. Нью-Йорк: Видання Спілки украӥнської молоді Америки, 1954. С. 7.

9. Ерріо про франко-радянські взаємини // Вісті ВУЦВК. 20 вересня 1933.

10. Звичайна О. Селянська санаторія / О. Звичайна. Вінніпег: Тризуб, 1952. 218 с. с. 15.

11. Звичайна О., Млаковий М. Ворог народу : повість у 2-х т. T. 1. Проти течії / О. Звичайна, М. Млаковий. Лондон: Украӥнська видавнича спілка, 1966. $468 \mathrm{c}$.

12. Мак О. Каміння під косою. Торонто: «Гомін України», 1973. 158 c.

13. Мак Ольга (Геи,, Петрова) / Украӥнський голокост 1932-1933: Свідчення тих, хто вижив. Київ: Вид. дім «Києво-Могилянська академія», 2008. T. 5. / Упор.: Ю. Мичик, І. Вінницька. 2008. 322 с.
14. Маляр П. Золотий дош. Роман-трилогія. Поема про Улянку. Торонто: Нові Дні, 1975. 119 с.

15. Письменники на хлібозаготівлях // Літературна газета. 10 січня 1933 p.

16. Розстріляне відродження: Антологія 1917-1933. Поезія - проза - драма - есей / Упор. Ю. Лавріненко. К.: Смолоскип, 2008. 976 с.

17. Спеичповідомлення «Про самогубство письменника Хвильового» // Полювання на «Вальдшнеnа». Розсекречений Микола Хвильовий / Упор. Ю. Шаповал. К.: Темпора, 2009. 296 с.

18. Хвильовий М. Г. [Некролог] // Харківський пролетар. 15 травня 1933 p.

19. Шаян В. П. Подолавши в собі бажсання смерти... / В. П. Шаян // Звичайна О., Млаковий М. Ворог народу : повість у 2-х т. Т. 1. Проти течії / O. Звичайна, М. Млаковий - Лондон: Украӥнська видавнича спілка, 1966. С. 5-14.

20. Шерех Ю. Принциипи і етапи большевицької політики щьодо слов'янських мов в СРСР (крім російської) / Ю. Шерех // Свобода. 1947. № 277.

\section{REFERENCES}

1. Gai-Golovko O. Poyedinok z diyavolom: filmyu nashih dniv / O. Guy-Golovko. Winnipeg, 1950. 143 s. [in Ukrainian].

2. Gai-Golovko O. Smertelnoyu dorogoyu: Podiyi nashogo chasu / O. Guy-Golovko. Winnipeg, 1983. $283 \mathrm{pp}$. [in Ukrainian].

3. Galan Anatol. Peredmova // Pratsya I nagoroda Zosima Donchuka / Uporyad. L. Donchuk. Filadelfia: Vlasna Hata, 1973. S. V-XIII. [in Ukrainian].

4. Donchuk Z. I bachiv ya...: Roman. Filadelfia, 1967. 324 s. [in Ukrainian].

5. Donchuk Z. Ostanniy Velikden na Poltavshine // Chorni Dni. Buenos-Aires, Filadelfia, 1952. S. 3943. [in Ukrainian].

6. Donchuk Z. Prirva. Chikago, 1959. 560 s. [in Ukrainian].

7. Donchuk Z. Cherez richku. Buenos-Aires: Peremoga, 1953. 140 s. [in Ukrainian].

8. Ereme. Golod. New-York: Vidannya Spilki ukrainskoyi molodi Ameriki, 1954. P. 7 [in Ukrainian].

9. Errio pro franko-radyanski vzaemini // Visti VUCVK. 20 veresnya 1933 [in Ukrainian].

10. Zvichayna O. Selyanska sanatoriya / O. Zvichayna. Winnipeg: Triyzub, 1952. 218 s. [in Ukrainian].

11. Zvichayna O., Mlakoviy M. Vorog narodu: povist $u$ 2 t. T. 1. Proti techiyi / O. Zvichayna, M. Mlakoviy. London: Ukrainska vidavnicha spilka, 1966. 468 s. [in Ukrainian].

12. Mack O. Kaminnya pid kosoyu. Toronto: Homin Ukraini, 1973. 158 s. [in Ukrainian].

13. Mack Olga (Gets, Petrova) / Ukrainskiy Holocaust 1932-1933: Svidchennya tih, hto vigiv. Kiyiv: Vuid. dim "Kievo-Mohylanska akademiya", 2008. T. 5. I Uporyad: Y. Mitsik, I. Vinnitska. 2008. 322 s. [in Ukrainian].

14. Malyar P. Zolotiy dosh. Romen-trilogiya Poem pro Ulyanku. Toronto: Novi Dni, 1975. 119 s.

15. Pismenniki na hlibozahotivlyah // Literaturna gazeta. 10 janvarya 1933 [in Ukrainian].

16. Rozstrilyane vidrodgennya: Anthologiya 19171933: Poeziya - prosa - drama - essay / Upor. Yu. Lavrinenko. K .: Smoloskyp, 2008. 976 s. [in Ukrainian].

17. Specpovidomlennya report "Pro samogubstvo pismennyka Khvilyovogo" // Polyuvannya na "Waldshnepa". Rozsekrecheniy Mikola Khviloviy / Upor. Yu Shapoval. K .: Tempora, 2009. 296 s. [in Ukrainian].

18. Khvyloviy M.G. [Nekrolog] // Kharkivskiy proletar. 15 travnya 1933 [in Ukrainian].

19. Shayan V. P. Podolavshi v sobi bazannya smerti... / V.P. Shayan // Zvichayna O., Mlakoviy M. Vorog narodu: povist u 2 t. T. 1. Proti techiyi / O. Zvichayna, M. Mlakoviy. London: Ukrainska vidavnicha spilka, 1966. 468 s. [in Ukrainian]. 